\title{
Racism, Feminism and Language in Zora Neale Hurston's Their Eyes Were Watching God
}

\author{
Sawsan Qashgari \\ Department of Foreign Languages \\ Taif University, Saudi Arabia
}

\begin{abstract}
Their Eyes Were Watching God by Zora Neale Hurston has received mixed reviews over Hurston's treatment of African Americans' struggle. Her African American male contemporaries saw her novel as an oversimplification of racial issues. Nevertheless, a closer reading of her book proves otherwise. This paper explores her powerful, albeit subtle, portrayal of the desperation imposed not only on her race, but on her gender as well. Hurston masterfully represents racial and gender issues without resorting to the anger and hostility that appear in the works of most of her contemporary African American male writers such as Richard Wright. Hurston's characterization of the female protagonist, her skin-color, and even the language she uses, allows her to draw an accurate image of the African American woman in the early 1900s. Her choice of the African American dialect grants Janie Crawford a voice of her own despite society's constant attempts to silence her. Focusing on the context and Hurston's narrative and language, this paper aims at asserting that Their Eyes Were Watching God is not merely a tragic love story; it is a skilful representation of race, gender and class issues in America at that period of time.
\end{abstract}

Key Words: Hurston, female voice, racial conflicts, African American dialect, African American women, gender oppression

Cite as: Qashgari, S. (2017). Racism, Feminism and Language in Zora Neale Hurston's Their Eyes Were Watching God. Arab World English Journal for Translation \& Literary Studies, 1(2). DOI:http://dx.doi.org/10.24093/awejtls/vol1no2.3 
Zukin (2010) refers to the Harlem Renaissance as the age of "extraordinary creativity" in the history of African American literature (p. 65). The years between 1919 and 1940 witnessed the rise of African American works of art with more "confidence" and influence than before. The Harlem Renaissance produced many brilliant artists, poets, writers, etc. (Gates\& McKay, 1997,pp. 953, 1019) During this era, African American literature was seen by black writers as a device for representing white American racism and brutality and how these impacted the lives and personalities of Afro-Americans. However, Zora Neale Hurston, as an African American writer, charted a different path in her novel Their Eyes Were Watching God (Hurston, 1937).

The novel is about Janie Crawford and her return to her house in Eatonville. The narrative unfolds the details of Janie's life journey as she narrates it to her friend Pheoby. Janie tells Pheoby about her life experience starting with her two husbands Logan Killicks and Jody Starks, and how she was forced by her grandmother to marry Logan and the reasons why she escaped from him to Eatonville with Joe Starks with whom she lived for twenty years until he died. Janie concludes her story with her romantic relationship with Vergible Woods "Tea Cake", which ended tragically when Janie shot him.

Gray (2004) describesTheir Eyes Were Watching God as Hurston's “masterpiece” (p. 514).It is a story of Janie who faces several barriers through her life that fall into three categories: race, gender and class. She is on an identity quest which can be achieved only by means of eliminating all the boundaries that faced the African American woman in her age. Whereas Wall (2000:5) interprets Janie's journey as a pursuit of a romantic relationship, other critics believe that Janie's real ambition is to find her own voice and identity in a society dominated by men. Gray (2004), for instance, argues that Hurston's novel reveals "how one remarkable woman fulfils the promise of her life by insisting on her own right to participate in the speaking and the ceremonials" (p.515). For McKay (1990), Their Eyes Were Watching God follows Janie's "psychological development from a male-identified woman to a self firmly grounded in a positive sense of independent black womanhood" (p. 55).Gates (1989) also describes the novel as the story of "the quest of a silent black woman ... to find a voice" (p. 169).Nevertheless, gender is not the only matter treated by Hurston, as Benesch (1988) explains: "there is more at stake [in the novel] than a confrontation of gender-related interests: oppositions such as people versus things, communication versus isolation, blackness versus whiteness" (p. 628).In addition to dealing with these issues, Their Eyes Were Watching God is also a love story that Mary Helen Washington praised for being "the most beautiful love story of a black man and woman in literature" (Wall, 2000:11).

Hurston's novel received contradictory reviews from both black and white critics when it was published. It was "largely ignored" and "greatly criticized" by Hurston's African American male contemporaries, whereas it was celebrated by feminist critics (Lester, 1999:xiii). Her novel received negative reviews by her contemporary African American scholars and critics because it lacked the treatment of racial issues. Throughout that age, African American writers had a tendency towards writing about the confrontations between the two races and how the African Americans suffered from the racist laws and behaviours. Gates (2000) argues that "black authors wrote almost exclusively about their social and political condition as black people living in a society in which race was, at best, problematical". They focused on racial topics in an attempt to assert their position as equals to the white Americans and to "speak for themselves" (Gates, 
2000:62). Awkward (1990) argues that black artists' principal duty was to construct protesting literature that represents the historical mistreatment of African Americans by whites and to increase the African Americans' self-esteem. Hurston, on the other hand, does not address racism directly or as aggressively as her contemporaries. Therefore, as Awkward observes, she was accused of trying to be a "perfect "darkie" whose works aim at satisfying white readers and scholars (Awkward, 1990:3). Her novel, Their Eyes Were Watching God, was harshly criticized by her fellow black male writers. Hurston's novel received its most hostile criticism from Richard Wright, the author of Native Son (1940), who argues that the novel "carries no theme, no message, [and] no thought" (Awkward, 1990:11).Gates (2000) comments on the antithetical difference between Hurston and Wright by arguing that "no two authors in the tradition are more dissimilar than Hurston and Wright"(p.75).Wright wrote more aggressive and angry novels than Hurston.Even though the novel does not provide a direct furious protestation against racism, it portrays its impact on the black society as effectively as any other black contemporary literary work that focuses on racial violence imposed on African Americans.

In the second chapter of the novel, the reader is introduced to Janie's grandmother, Nanny. Nanny asserts to Janie that white Americans are at the top of the social hierarchy, "Honey, de white man is de ruler of everything as fur as Ah been able tuh find out" (19). Nanny was born in slavery and she suffers from the abuse practiced on women slaves. She was subjected to the "habitual rape" by her white master who was responsible for her pregnancy with Leafy. In addition to these habitual afflictions, Nanny had to endure her master's abandonment of her daughter Leafy whom she raised bearing all the obstacles that had faced her personally. Nanny prays that her daughter would have a brighter future but her dreams vanish when Leafy is raped by her schoolteacher. The heroine of the novel, Leafy's daughter, was not born in slavery, yet she is a victim of racism in one way or another. After Nanny sees Janie having her first kiss with Johnny Taylor, she becomes aware of Janie's sexual maturity and she tries to protect her from the miserable life she had by forcing her to marry an old man who owns a sixty-acre lot of land and a mule. And soon Janie loses her identity and dreams as a result of her grandmother's anxiety which was caused by her struggle under slavery. Kaplan (2000) comments on Hurston's portrayal of racism by saying that her depiction of Nanny's story "parodies it nearly as derisively as did some of her male colleagues" (p. 146).

Furthermore, the trial which is held after Janie shoots her third husband Tea Cake is further evidence of the presence of the theme of racism. In Janie's murder trial, the white men are the ones who decide whether Janie is guilty or not. The judge is white, the twelve men in the jury are white and the white Americans are seated in the front while the blacks stand in the back. The judge and the jury justify Janie's murder and clear her from the charges after the testimony of a white doctor who explains that Tea Cake was bitten by a rabid dog and that Janie killed him in self-defence. African Americans are sat at the back; they do not get a chance to testify against her; therefore, they insist that had the victim been white, Janie would have been found guilty, one of them says: "She didn't kill no white man, did she? Well, long as she don't shoot no white man she kin kill jus' as many niggers as she pleases" (p.253). By showing the white Americans in the position of authority, Hurston draws the real image of racism and how whites control blacks.

Moreover, Hurston's novel does not only approach racism from a limited perspective as being between blacks and whites; she broadens the concept of racism into what Lester refers to 
as "intra-racism". According to Lester (1999), the racial discrimination is based on the skin colour even among African American communities. The "light-skinned" person is treated better than the "dark-complexioned" black person for the fact that lighter-skinned people have white blood in their veins (pp. 93-99). Bertice Berry (1999) points out that during that age, the variety of the white society's perceptions of African Americans was controlled by their skin colour, she comments: "if you were light you were all right, brown you could stick around, but if you were black, you had to get back" (p. 96). Hurston skilfully represents this "intra-racism" through the character of Mrs Turner. Mrs Turner is a black woman who, on account of her pointed nose and thin lips, is proud of not looking like "Negroes". She believes that "white European features are cherished and black Negroid features are lamented" (Lester, 1999: 93). Although she is black, Mrs Turner is as racist as any white American . She asserts her hatred for blacks as she declares her understanding of the reasons why white people despise blacks, she says: "Ah can't stand black niggers. Ah don't blame de white folks from hatin' 'em 'cause Ah can't stand 'emmahsself' (188-89). Janie is introduced to Mrs. Turner after she leaves Eatonville with Tea Cake and stays at the muck in the Everglades. Mrs. Turner urges blacks to marry lighter-skinned people in order to "lighten up de race" (188). She tries to convince Janie to leave Tea Cake and marry her brother instead. She thinks that a woman with Janie's beautiful features (luxurious straight-hair, thin-lips, high nose and coffee-and-cream complexion) should not marry a darkskinned man like Tea Cake. However, Mrs. Turner thinks that Janie's faulty decision of marrying Tea Cake can be corrected only through divorcing him and marrying her brother. By portraying the character of Mrs. Turner, Hurston asserts that racism is more pervasive in American society than the typical confrontations between blacks and whites. Plus, during the court scene, Hurston emphasizes intra-racism when a black man objects to the way Janie has been justified, believing that her light skin is the reason for her acquittal. He says: "Aw you know dem white menswuzn'tgointuh do nothin' tuh no woman dat look lak her” (252).

The claim that Hurston's novel neglects the racial issues is poorly founded. In fact, Hurston's depiction of racism in Their Eyes Were Watching God is as skilful and effective as that of Richard Wright in his novel Native Son (1940) and Ralph Ellison in Invisible Man (1952) (Lester, 1990:94).Lester (1990) argues that instead of showing the violence and hostility between African Americans and whites the way it is represented by Wright and Ellison, Zora Neale Hurston's "social protest" is presented through "decentring" the white society and its existence in her "celebration of the fullness of black existence". Hurston's novel draws an image of an African American community in Eatonville that survives the social, political and economic obstacles imposed by white Americans. The novel's incidents are focused on the African American society while white people are pushed to the margins of the narrative. Despite the fact that they own the authority and power, white Americans have no presence in the perfect portrait of this community in Eatonville (p. 90).

By contrast to the negative reviews of some African American critics like Wright, female critics honoured Hurston for portraying the life and struggle of African American women, and womanhood in general, under male dominance. Alice Walker explains that the importance of the novel is due to addressing womankind and their inner feelings, she argues: "It speaks to me as no novel, past or present, has ever done" (Hurston, 1986, back cover). McKay (1990) describes Janie's story as a reflection of the African American women's efforts "to liberate themselves and all black people from the oppression of race and sex through the power of language and the 
struggle to own their history" (p. 55).Washington (2000), similarly, believes that the novel represents women's "exclusion" from power and particularly the power of "oral speech". She argues that the society in that period had a tendency towards "silenc[ing] women" and, moreover, to make them conspirators in that silence (pp. 27-28).Wolff (1982) indicates that the beginning of Hurston's novel points to the difference between men and women through the fact that women are more realistic than men. Men have "inner hopes" that can be achieved only through uncontrollable factors. For them "life is given, not made". On the other hand, women "create their own lives from their interpretations of reality" (p. 29). Wolff argues that this fact is drawn by Hurston as she opens her novel with affirming that "ships at a distance have every man's wish on board" and she continues by declaring that for women "the dream is the truth. Then they act and do things accordingly" (1).

Through the story of Janie's grandmother, the novel points out how African American women were repressed by their society. Nanny reveals to Janie that while the male is controlled by his white master, he tries to practice his power on the African American woman. She says: "de white man throw down de load and tell de nigger man tuh pick it up. He pick it up because he have to, but he don't tote it. He hand it to his womenfolks" (19). Moreover, the novel makes several references to the fact that these women are placed in an equal position to animals by men. Joe Starks, Janie's second husband, states that women, like animals, have no ability to think and decide what is best for them and therefore they should be controlled by men and their thoughts and decisions, he says to Janie: "Somebody got to think for women and chillun and chickens and cows. I god, they sho don't think none theirselves" (95). Nanny, as well, redraws this image to Janie as she says to her: "De nigger woman is de mule uh de world so fur as Ah can see" (19). Yet, Nanny's indication of the similarity between women and mules is more positive than Joe's suggestion that women are as primitive as animals. Nanny compares the strength of the African American woman to the strength of the mule; she carries the loads that are thrown on her shoulder by men of both races, in addition to white women, without complaining. Davie (1993) explains the symbolism of the mule as the fact that for white Americans, "blacksseemed to slide into the category of animal-a convenient justification for owning them" and African American men see their wives and female mates in the same way so as to justify controlling them (p. 449).

In another feminist gesture, Hurston uses the trial scene not only to discuss the racial issues but goes further to discuss gender-related matters. Du Plessis (1990) describes this scene as "the main place in which race and gender, as well as class and sexuality, show intense cross-purposes and mutual conflicts" (p. 102). In her trial, Janie faces white men, white women and African American men, The only group that shows sympathy for her is the white females. Hurston implies through this scene that white women are more affectionate towards African American women than the African American man despite the race difference.

In addition to being socially at the bottom, African American women had to suffer from the violence of the men in their lives. In order to preserve their superiority over women and to keep them silent, men resolve to violent behaviours. Janie faces physical and emotional brutality not only from her three husbands but from her grandmother as well. Nanny slaps Janie when she objects to marrying Logan Killicks. She slaps Janie to show her that the man is the ruler, the one who has the upper hand in society and the only one who is capable of protecting her, and as such, deserving respect and obedience (Lester, 1999:81). In this scene, the grandmother adopts the 
male gaze and she treats Janie accordingly. After marrying Killicks, Janie faces another kind of cruelty. Logan is like a "slave master", he forces Janie to work for him in his barn. He treats her as if she is an animal; in fact, Janie becomes his second mule. He says to her: "You ain't got no particular place. It's wherever I need you" (42). When Janie refuses to obey his orders and commands and to be treated as a slave, he resorts to insulting her. He threatens her and reminds her that he is her benefactor since he kept her from becoming a slave for white people, "Ah just as good as take you out de white folks' kitchen" (42). Consequently, when Joe Starks starts telling her with his rhythmic words how she should be treated as a lady and to be served rather than being the servant; she is tempted to leave Logan and to escape with Jody. Unfortunately, Janie discovers that Jody used his sweet rhymes and words to deceive her into becoming his wife as part of his plan to become a "big voice" (38). Soon after leaving with him, he gets busy building the first state of African Americans in Eatonville hoping to be elected its mayor. He builds a nice house for Janie and himself and he buys her precious things. He aspires to make her the perfect mayor's wife who speaks acts and dresses according to his designs. In the process of establishing his "big voice", he silences Janie and restricts her freedom. He slaps her once "until she had a ringing sound in her ears" (96) because his dinner was not as good as he expects it. Janie, however, decides to fight him back after a twenty-year marriage and when she does, he strikes her with all his power and gets her out of his store. After Joe dies Janie meets Tea Cake whom she believes can be the man of her dreams and she lives with him the happiest days of her life. Nevertheless, Tea Cake proves to be the opposite with his mistreatmentfor her and the way he uses her sometimes. He, as well as Logan and Jody, treats her with violence in a few occasions. Her life with him becomes an "emotional rollercoaster". One night he steals her money and stays out of the house, but he returns to her apologizing for his deeds. In another scene, he hits her to show her that he is the man and to ascertain his masculinity (Lester, 1990, pp. 5, 81).

Janie loathes being abused by Logan and Jody, and she punishes them knowing exactly how to pay them back. She is aware that Logan's idea of masculinity lies in his ownership and possession and since he considers her part of his possessions, she punishes him by abandoning him and marrying Jody. Her punishment for Jody is more aggressive and hostile. Janie realises that he values his masculinity for he sees it as part of the image he wants to reflect for the townsfolk to confirm his position in society. Thus, she confronts him and insults him in the store in front of the citizens of Eatonville. Soon afterwards, Jody dies. Lester argues that after Janie explodes a bomb in Jody's face, he "dies twice - metaphorically and then shortly thereafter quite literally" because he refuses to be looked at with pity by others.Although Janie rebels against Logan and Jody, she bears Tea Cake's mistreatment because he makes her feel the "vulnerabilities of love and passion" (Lester, 1990:81).

Janie's rebellion against male sadism is not the only aspect of the novel celebrated by feminist critics. According to Brantly (2004), Hurston offers "many challenges to the notion that women must be passive with needs defined solely by men" (p. 474). Janie's search for her voice and identity is the most debatable theme in Hurston's novel. Hurston's novel is considered as a "record" of Janie's struggle to find "voice and through voice an identity" (Kaplan, 2000:140).Awkward (1990) agrees as he points out that Hurston follows "Janie's movement toward self-actualization" (p. 16). However, Lester (1990) disagrees with them by arguing that Janie is in a quest not for identity but for freedom. She searches for the freedom to be herself, to 
make her own choices in life and to accept the consequences of her choices (p. 4). Janie's freedom is contained by her grandmother in her youth when she forces her to marry Logan. Moving from Nanny's control, she is given the role of a slave and she is even dragged by Logan Killicks to work in the barn like an animal. Then she attempts to free herself from him by escaping with Joe Starks without divorcing Logan. Unfortunately, Joe controls her life and restricts her freedom in different ways. First, he controls her appearance by making her wear the clothes that he chooses and by obliging her to tie up her hair and cover her head with a headkerchief. He also forbids her from participating in the social ceremonies and from taking part in the conversations of the people of Eatonville. After his death, Janie finally gets a taste of freedom, especially after she meets Tea Cake. Only with Tea Cake that Janie experiences the real meaning of romance and freedom.Tea Cake's real name is Vergible Woods. It symbolizes Janie's tree; he is the woods themselves". It is derived from "veritable woods", which signifies purity and genuine love (Gates, 2000:83). Even though she is still under a male dominance, she still feels free and loved. Despite the disapproval Janie faces from the citizens of Eatonville, she chooses to leave her house with Tea Cake who is much younger than her. She leaves to a lower state of life in an unknown place. She aspires to find the happiness that she has spent all her life looking for in leaving the classy life she has in Eatonville. Her desire to explore the unknown is similar to the speaker's curiosity in Gwendolyn Brooks' poem:

I've stayed in the front yard all my life.

I want a peek at the back

Where it's rough and untended and hungry weed grows.

A girl gets sick of a rose.

I want to go in the back yard now

And maybe down the alley,

To where the charity children play.

I want a good time today.

They do some wonderful things.

They have some wonderful fun (Gates\& McKay, 1997, p. 1626)

Eatonville and the porch of her house function as the front yard of Janie's life. She chooses to see the other side of the world hoping to find the fulfilment of the dreams that she could not find in her earlier secured life. Her relationship with Tea Cake guarantees her both romance and freedom. He is not obsessed with money and power like Logan and Joe; he regards money as a source of joy and entertainment. He regards life with a joyful look. Mary Washington (2000) justifies Janie's excitement and happiness in her life with Tea Cake by suggesting that the mystery, "the sense of risk and helplessness" and the secrecy of their relationship in its early stages are the reasons why Janie finds her affair with Tea Cake as an irresistible adventure (p. 37). Tea Cake teaches Janie how to shoot and how to protect herself without needing male protection. However, Tea Cake is "less than [the] ideal mate" for Janie. He steals from her, hits her and after the hurricane he gets bitten by a rabid dog. His charming personality and passionate love start fading under the influence of the illness. Eventually, Janie is forced to shoot him to protect herself and to preserve what she "loves and cherishes" in him (Awkward, 
1990:17).Kaplan (2000) regards this tragic closure to their love to be within the "narrative logic" since Tea Cake's death allows Janie to continue her quest and to "satisfy" her longing for her independence of, and freedom from, any male dominance (p. 154). After Tea Cake's death and the end of her trial, Janie returns to Eatonville to her house. She "come[s] home to her true speech, and her true self" (Gray, 2004:515).

Kaplan (2000) makes a similar point as she argues that Janie's search is not for a voice, in fact she "had one all along". Kaplan suggests that Janie is indeed searching for a good listener. Nanny refuses to listen to her when she reveals to her that she wants to find true love instead of marrying Logan. Jody and Logan also choose to ignore her and her need for expressing herself by silencing her. Tea Cake is the first one to allow her to speak for herself and actually listens to her. However, he turns into a bad listener when he refuses to listen to the Indian who advises them to leave the muck before the hurricane strikes. His ignorance leads to the tragic end of their marriage when he gets rabies. Plus, the people in Eatonville are bad listeners as well since their main concern is to gossip about people instead of seeking the truth of their lives. Janie says to her friend: "Ah don't mean to bother widtellin' 'emnothin', Pheoby. 'Tain't worth de trouble" (p.8). Only Janie's friend Pheoby proves to be a worthy listener and that is why Janie decides to tell her the story of her life. Janie says: "[M] uh tongue is in mah friend's mouf" (p.8) meaning that she is the only one who can listen to her and understand what she is saying and appreciate her feeling so one day she can recount Janie's story to the rest of the world (Kaplan, 2000:140154).

Regardless of the debate on whether Their Eyes Were Watching God addresses racial issues or not, and whether Hurston represents African American women's search for a voice, or identity; various critics admire Hurston's skill in portraying an honest image of the African American society through her use of language and the Southern black dialect. Terry (2004) describes Their Eyes Were Watching God as a "foundational text" as a result of Hurston's choice of authorial voice and because she "values the vernacular dialect" of the Southern black community (p. 525). Gray (2004), as well, agrees that Hurston's use of dialect "shows how a small group of people ground themselves" (p. 515). Awkward (1990) argues that Hurston's narrative strategy "gives a voice to the voiceless" community (p. 20). African Americans have been criticized by white Americans because of their "inability to master standard English" (Lester, 1999:21) and Hurston's use of the "negro" dialect confirms their ability to establish their own speech without having to use standard English. She proves that the Southern black dialect is as expressive as the white American's dialect. By asserting the capability of black language to "convey an extraordinarily wide variety of ideas and feelings", Hurston determines that the most eligible representatives of the black society are the black people themselves. She narrates the novel in the form of a frame starting with the scene in which Janie reveals to Pheoby her story and closes with the same scene as she reaches the end of her story. Hurston uses the third-person narrator who uses standard English but she delivers the speeches of the characters using the black dialect. She mixes the most two "extreme...modes of narration" to show that African Americans are different from the rest of the world, yet they are independent individuals with their own culture and history (Gates, 2000, pp. 84, 92, 93).

Zora Neale Hurston celebrated her "greatest achievement" through Their Eyes Were Watching God (Zelinsky\& Cuomo, 2004:282); a novel that celebrates the complexity of African American society and their language, portrays the dark side of racism and follows a black 
AWEJ for Translation \& Literary Studies volume, 1 Number 2, May2017

Racism, Feminism and Language in Zora Neale Hurston's Their Eyes

Qashgari

female's search for identity and freedom. It represents one woman's courage to go beyond the luxurious life and to explore the real beauty of life and love. It is a story that never ends because "there is no end to reach" (Gates, 2000:95).

\section{About the Author:}

Dr. Sawsan Qashgari graduated from Taif University with honours in 2007 with an English major and a minor in Education. In 2011, she received an MA degree in American Literature from the University of Essex in the UK. In 2015, she was awarded a Doctorate of Philosophy in American Literature from the University of Essex. Since then, she has been working as an Assistant Professor at Taif University.

\section{References}

Awkward,M.(Ed.). (1990).New Essays on Their Eyes Were Watching God. New York: Cambridge University Press.

Benesch, K. (1988). Oral Narrative and Literary Text: Afro-American Folklore in Their Eyes Were Watching God.Callaloo,36,627-635

Berry, B.(1999). Vision of Black Beauty Shaded by Colorism. InN. Lester (Ed.), UnderstandingZora Neale Hurston's Their Eyes Were Watching God (pp. 96-99). London: Greenwood Press.

Brantley,W. (2004). Zora Neale Hurston. In R. Gray \& O. Robison (Eds.), A Companion to the Literature and Culture of the American South (pp. 472-485).Oxford: Blackwell Publishing.

Davie, S. (1993, May). Free Mules, Talking Buzzards, and Cracked Plates: The Politics of Dislocation in Their Eyes were Watching God. PMLA, 108 (3),446-459.

Du Plessis, R. (1999). Power, Judgement, and Narrative in a Work of Zora Neale Hurston: Feminist Cultural Studies. In M. Awkward (Ed.), New Essays on Their Eyes Were Watching God(pp. 95-123). New York: Cambridge University Press.

Gates, H., \& McKay, N. (Eds.) (1997). The Norton Anthology of African American Literature. New York: W.W. Norton \& Co.

Gates, H. (1989). The Signifying Monkey: A Theory of African-American Literary Criticism. New York: Oxford University Press.

Gates. H. (2000). Zora Neale Hurston and the Speakerly Text. In C. Wall (Ed.), Zora Neale Hurston's Their Eyes Were Watching God: A Casebook(pp. 59-116). New York: Oxford University Press.

Gray, R. (2004).A History of American Literature. Oxford: Blackwell Publishing.

Kaplan,C. (2000). The Erotics of Talk: "That Oldest Human Longing" in Their Eyes Were Watching God. In C. Wall (Ed.),Zora Neale Hurston's Their Eyes Were Watching God: A Casebook(pp. 137-164). New York: Oxford University Press.

Lester, N.(1999).UnderstandingZora Neale Hurston's Their Eyes Were Watching God. London: Greenwood Press.

McKay,N. (1990). "Crayon Enlargements of Life": Zora Neale Hurston's Their Eyes Were Watching God as autobiography. In M. Awkward (Ed.),New Essays on Their Eyes Were Watching God (pp. 51-70). New York: Cambridge University Press.

Terry, J.(2004). Oral Culture and Southern Fiction. In R. Gray \& O. Robison (Eds), A Companion to the Literature and Culture of the American South(pp. 518-535). Oxford: Blackwell Publishing. 
AWEJ for Translation \& Literary Studies volume, 1 Number 2, May2017

Racism, Feminism and Language in Zora Neale Hurston's Their Eyes

Wall,C. (Ed). (2000). Zora Neale Hurston's Their Eyes Were Watching God: A Casebook. New York: Oxford University Press.

Washington, M.(2000). "I Love the Way Janie Crawford Left Her Husbands": Zora Neale Hurston's Emergent Female Hero. In C. Wall (Ed.),Zora Neale Hurston's Their Eyes Were Watching God: A Casebook(pp. 27-40). New York: Oxford University Press.

Williams, S. (2000). Encountering Zora Neale Hurston. In C. Wall (Ed.), Zora Neale Hurston's Their Eyes Were Watching God: A Casebook (pp. 19-25). New York: Oxford University Press.

Wolff, M. (1982). Listening and Living: Reading and Experience in Their Eyes Were Watching God. Black American Literature Forum, 16 (1), 218-229.

Zelinsky, M. \& Cuomo, A. (2004). Southern Drama. In R. Gray and O. Robison (Eds.),A Companion to the Literature and Culture of the American South(pp. 280-296). Oxford: Blackwell Publishing.

Zukin, S. (2010). Naked City: The Death and Life of Authentic Urban Places. New York: Oxford University Press. 